\title{
MENGGALI SUMBERDAYA GENETIK UDANG JERBUNG (Fenneropenaeus merguiensis de Man) SEBAGAI KANDIDAT UDANG BUDIDAYA DI INDONESIA
}

\author{
Eni Kusrini \\ Balai Riset Budidaya Ikan Hias \\ Jl. Perikanan No.13, Pancoran Mas, Depok \\ E-mail: ennyperikanan@yahoo.com
}

\begin{abstract}
ABSTRAK
Udang jerbung (Fenneropenaeus merguiensis de Man) merupakan salah satu jenis udang penaeid yang mempunyai nilai ekonomis tinggi. Habitat asli udang jerbung tersebar di seluruh perairan Indonesia mulai dari Aceh sampai Irian dan merupakan udang yang tertangkap dalam kumpulan yang cukup besar. Udang ini bersifat bentik; hidup pada permukaan dasar laut. Semua perairan Indonesia mempunyai potensi untuk pengembangan budidayanya. Pengembangan budidaya udang jerbung membutuhkan stok induk dan benih yang berkualitas baik. Induk dan benih tersebut dapat diperoleh melalui program pemuliaan selain dari seleksi tangkapan dari alam atau laut. Untuk mendukung program pemuliaan tersebut diperlukan informasi mengenai kondisi populasi udang jerbung di alam.
\end{abstract}

KATAKUNCI: udang jerbung, budidaya, perbenihan

\section{PENDAHULUAN}

Udang jerbung (Fenneropenaeus merguiensis de Man) sebelumnya memiliki nama ilmiah Penaeus merguiensis de Man (Farfante \& Kansley, 1997), merupakan udang komersial yang mempunyai nilai ekonomis tinggi. Secara lokal udang tersebut banyak disajikan di restoran sea food dengan harga cukup tinggi. Dalam dunia perdagangan udang jerbung mempunyai banyak nama dagang misalnya di Hongkong dinamakan white prawn, di Australia banana prawn atau white shrimp, di Malaysia udang kaki merah, dan di Indonesia dikenal dengan nama udang putih, menjangan, udang perempuan, udang popet, udang kelong, udang peci, udang pate, udang cucuk, pelak, kebo, angin, haku, wangkang, pesayan, besar, manis, kertas, dan udang tajam (Martosubroto, 1977). Udang jerbung sebenarnya terdiri atas 3 kelompok yang secara visual sulit untuk dibedakan, yaitu: F. indicus, F. chinensis, F. orientalis, dan F. merguiensis.

Udang laut ini masih belum dibudidayakan padahal permintaan pasar ekspor cukup menjanjikan. Berdasarkan survai di lapangan udang jerbung ukuran ekspor (size 30) harganya dapat mencapai $\mathrm{Rp} 80.000$,- per $\mathrm{kg}$. Sampai saat ini pemenuhan pasar yang demikian tinggi masih dipenuhi dari tangkapan alam dan dampaknya adalah harga sangat fluktuatif sesuai dari hasil tangkapan. Pada musim-musim tertentu, bulan Februari-Mei udang ini sangat jarang ditemukan. Oleh karena itu, sangat mendesak untuk dilakukan budidayanya di samping udang windu maupun udang vaname. Udang jerbung ini layak menjadi kandidat budidaya tambak.

\section{SISTEMATIKA DAN BIOLOGI UDANG JERBUNG}

Udang jerbung (Fenneropenaeus merguiensis de Man) merupakan udang penaeid yang mempunyai klasifikasi umum sebagai berikut:

$\begin{array}{ll}\text { Filum } & \text { : Arthropoda } \\ \text { Kelas } & \text { : Crustacea } \\ \text { Sub kelas } & \text { : Malacostraca } \\ \text { Seri } & \text { : Eumalacostraca } \\ \text { Super ordo } & \text { : Eucarida } \\ \text { Ordo } & \text { : Decapopada } \\ \text { Sub ordo } & \text { : Natantia } \\ \text { Seksi } & \text { : Penaeidae } \\ \text { Famili } & \text { : Penaeinae } \\ \text { Genus } & \text { : Penaeus, Fabricius } 1878 \\ \text { Spesies } & \text { : Fenneropenaeus merguiensis de Man (1888) }\end{array}$

Secara umum morfologi udang jerbung (Gambar 1) tidak berbeda dengan udang yang lain. Tanda-tanda khusus yang membedakannya antara lain warna badan yang putih kekuning-kuningan dengan bintik coklat dan hijau. Ujung ekor dan kakinya berwarna merah, antennula bergarisgaris merah tua, dan antena berwarna merah. Gigi rostrum bagian atas 5-8 dan bagian bawah 2-5, ada juga yang mempunyai gigi rostrum atas 6-7 dan bawah 4-5. 


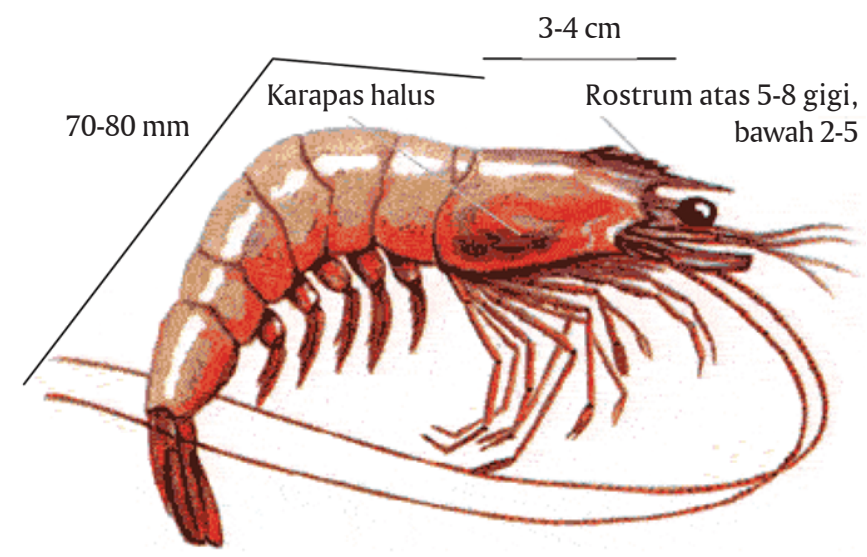

Gambar 1. Morfologi udang jerbung, Fenneropenaeus merguiensis

Pada karapas gastro orbital carinanya tidak ada atau tidak jelas. Periopoda pertama mempunyai duri isshial dan eksopodanya terdapat pada periopoda kelima. Abdomen, somit kelima mempunyai satu cicatrice, dan yang keenam mempunyai tiga cicatrace. Telson pada udang ini tidak berduri.

Habitat udang jerbung tersebar di seluruh perairan Indonesia mulai dari Aceh sampai Irian dan umumnya tertangkap dalam kumpulan yang cukup besar. Udang ini bersifat bentik; hidup pada permukaan dasar laut. Udang jerbung mempunyai daya adaptasi yang tinggi terhadap semua tipe dasar perairan, namun lebih suka untuk menghuni perairan lempung lumpur dan berpasir. Perairan yang berbentuk teluk dengan aliran sungai besar merupakan daerah yang baik untuk udang jerbung. Udang dewasa banyak ditemukan di perairan selasar (shelf), terutama perairan yang dekat dengan muara sungai, kadang-kadang dapat mencapai 60-80 mil dari pantai pada kedalaman 8-40 m (Naamin, 1975).

Dalam daur hidupnya, udang jerbung menempati dua daerah, yaitu laut dan air payau. Pemijahan terjadi di laut sepanjang tahun dengan puncaknya pada bulan Maret dan Desember. Induk udang yang matang telur biasanya memijah pada malam hari dan telur diletakkan di dasar laut. Kira-kira 12 jam setelah dikeluarkan, telur menetas menjadi larva pada stadia pertama yang disebut nauplius. Setelah mengalami pergantian kulit beberapa kali, nauplius berubah menjadi stadia zoea atau protozoea. Pada stadia ini, larva mulai mengambil makanan dari sekitarnya, dan selanjutnya bentuk zoea berubah menjadi mysis. Dari stadia mysis, larva bermetamorfosis menjadi stadia pasca larva yang bermigrasi ke perairan estuarin. Di perairan ini udang membenamkan diri pada siang hari di dasar yang lembek untuk menghindari gangguan predator sampai menjadi yuwana. Setelah berumur 3-6 bulan di daerah estuarin, yuwana turun kembali ke laut, tumbuh, dan berkembang sampai matang gonad di perairan laut dalam. Di sini udang muda mencapai tingkat kematangan dan bertelur. Beberapa spesies kadang-kadang hanya mencapai umur 12-14 bulan, udang dewasa akan mati setelah kembali ke perairan dalam dan bertelur (Gulland, 1971 dalam Koswara, 1985). Menurut Naamin (1975), udang jerbung yang normal dapat hidup selama 12 bulan dan kadang-kadang dapat mencapai 2 tahun.

Alat reproduksi udang jerbung bersifat heteroseksual. Jenis kelamin baru dapat dibedakan setelah tingkat post larva terakhir selesai. Petasma sebagai alat kelamin jantan terletak antara pasangan pertama kaki renang kelima, sedangkan telikum sebagai alat kelamin betina terletak antara pasangan kaki jalan keempat dan kelima. Udang dewasa memperlihatkan perbedaan ukuran yang jelas, karena udang betina lebih besar dari udang jantan pada umur yang sama (Kirkegaard et al., 1970 dalam Koswara, 1985).

Menurut Tuma (1967) dalam Naamin (1984), udang jerbung tidak mempunyai pasangan seks tertentu (promiscuous). Perkembangan telur dibagi menjadi lima tingkatan yaitu: dara (quiscent/undeveloped), berkembang (developing), hampir matang (early maturity/nearly ripe), matang (ripe), dan salin (spent). Pada tingkat dara dan berkembang ovari bening (translucent). Warna berubah menjadi kuning pada tingkat hampir matang, berwarna hijau gelap selama tingkat matang, dan hijau keabu-abuan selama tingkat salin. Sedangkan udang yang matang kelamin berada pada tingkat antara nearly ripe dan ripe. Pada tahap ini udang siap untuk bertelur.

Pertumbuhan udang jerbung secara umum sama dengan krustase yang lain, yaitu mulai dengan cara ganti kulit. Prosesnya meliputi melepaskan dirinya dari kulit luar (eksoskeleton), air diserap, ukuran udang menjadi bertambah besar, kulit luar yang baru terbentuk, dan air dalam jaringan secara bertahap diganti oleh jaringan yang baru. Nauplius mempunyai panjang sekitar $1 \mathrm{~mm}$, terdapat di atas dasar laut terbuka dengan salinitas 35 ppt selama 36-48 jam, kemudian berubah menjadi protozoea dengan panjang total sekitar $3 \mathrm{~mm}$. Stadium protozoea selama 7 hari bersifat planktonik bergerak menuju permukaan laut dan terbawa arus ke arah pantai. Protozoea berubah menjadi mysis berukuran panjang 4-10 $\mathrm{mm}$ dan bersifat planktonik selama 7 hari. Pasca larva adalah perubahan dari mysis dengan panjang $1-2 \mathrm{~cm}$, setelah berumur 1 bulan berubah menjadi yuwana dengan panjang 2-10 cm dan merupakan fase muara sungai selama 3-4 bulan. Udang dewasa merupakan fase lautan dengan panjang 10-24 cm sampai umur 8 bulan (Munro, 1968; Walker, 1974 dalam Naamin, 1984). 


\section{PENYEBARAN UDANG JERBUNG}

Udang jerbung merupakan spesies udang asli perairan Indonesia dan Asia Tenggara. Pada saat ini distribusi udang ini di Indonesia cukup luas mulai dari perairan Pulau Sumatera sampai Papua, dan bahkan hampir semua perairan Indonesia mempunyai potensi untuk pengembangan budidayanya. Berdasarkan data statistik nasional daerah produksi dari penangkapan udang jerbung paling besar untuk Pulau Sumatera adalah Bengkulu, Laut Jawa di Cilacap, dan Cirebon, sedang untuk Indonesia timur adalah Selat Lombok, Sulawesi Selatan, dan Arafura. Untuk gambaran umum distribusi secara lengkap disajikan pada Gambar 2.

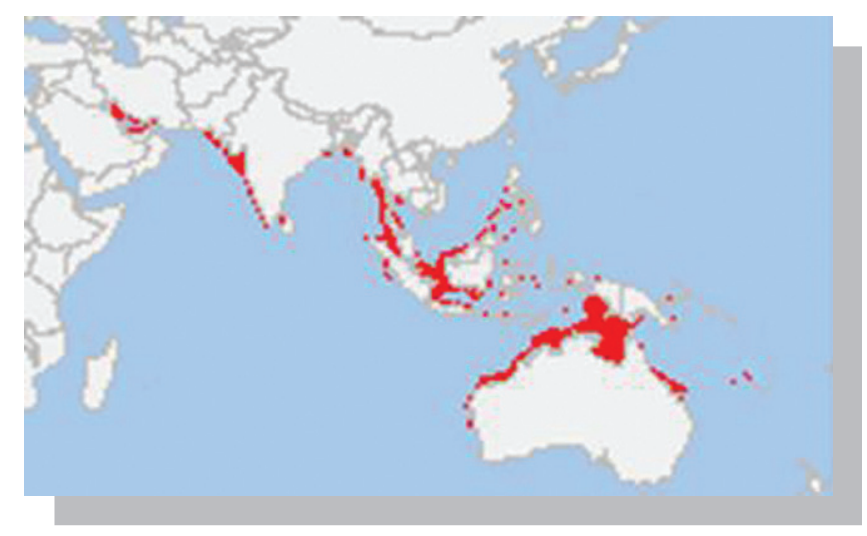

Gambar 2. Distribusi udang jerbung dari Australia dan Asia Tenggara terutama yang ada di Indonesia

\section{KANDIDAT UDANG BUDIDAYA}

Penangkapan udang jerbung secara terus-menerus dalam jumlah besar akan berakibat stok di alam dapat menurun. Oleh karena itu, usaha budidaya udang jerbung hendaknya segera dikembangkan. Tahap awal pengembangan budidaya membutuhkan stok induk dan benih berkualitas yang dapat diperoleh melalui program pemuliaan. Untuk mendukung program tersebut diperlukan informasi mengenai kondisi populasi udang jerbung di alam.

Pada tahun 1970 di Ujung Pandang, Sulawesi Selatan udang jerbung ( $F$. merguiensis) telah mengawali usaha untuk perbenihannya bersama-sama udang windu yang keduanya ditangkap dari laut, dipelihara dalam bak terkontrol. Perkembangan teknologi terus meningkat setelah kendala penyediaan induk matang telur dapat dipecahkan dengan berhasilnya inovasi teknologi pematangan gonad induk udang dengan rangsangan ablasi mata pada tahun 1978 (Cholik et al., 1988). Tetapi perkembangan teknologi perbenihan tersebut hanya difokuskan kepada udang windu, dari tahun ke tahun akhirnya proses pemijahan udang jerbung yang tertangkap bersama-sama udang windu tersebut tenggelam sampai saat ini dan belum pernah ada ceritanya lagi di sentra udang Indonesia Timur tersebut.

Beberapa daerah pesisir (Sulawesi Selatan, Cilacap, Bengkulu) para nelayan melakukan pembesaran udang ini di tambak hanya secara tradisional, merupakan sampingan dari udang windu yang dibesarkan bersama-sama udang windu di tambak yang sama. Benur dari hasil tangkapan, bukan dari budidaya (pembenihan). Pada tahun 1997 uji coba pembenihan di Daerah Situbondo oleh pihak swasta pernah dilakukan sampai ukuran tebar, dan dilakukan pembesaran pula di tambak. Namun, para petambak masih berfokus dengan udang windu yang pada saat itu sangat digalakkan pengembangannya sehingga kelanjutan usaha pembenihan udang jerbung terkalahkan. Informasi terkini yang diperoleh dari praktisi pembudidaya udang, pada saat ini usaha pembenihan di hatcheri sedang dilakukan di Daerah Bengkulu dan Papua, tetapi pertumbuhannya masih lambat sehingga belum kelihatan hasilnya.

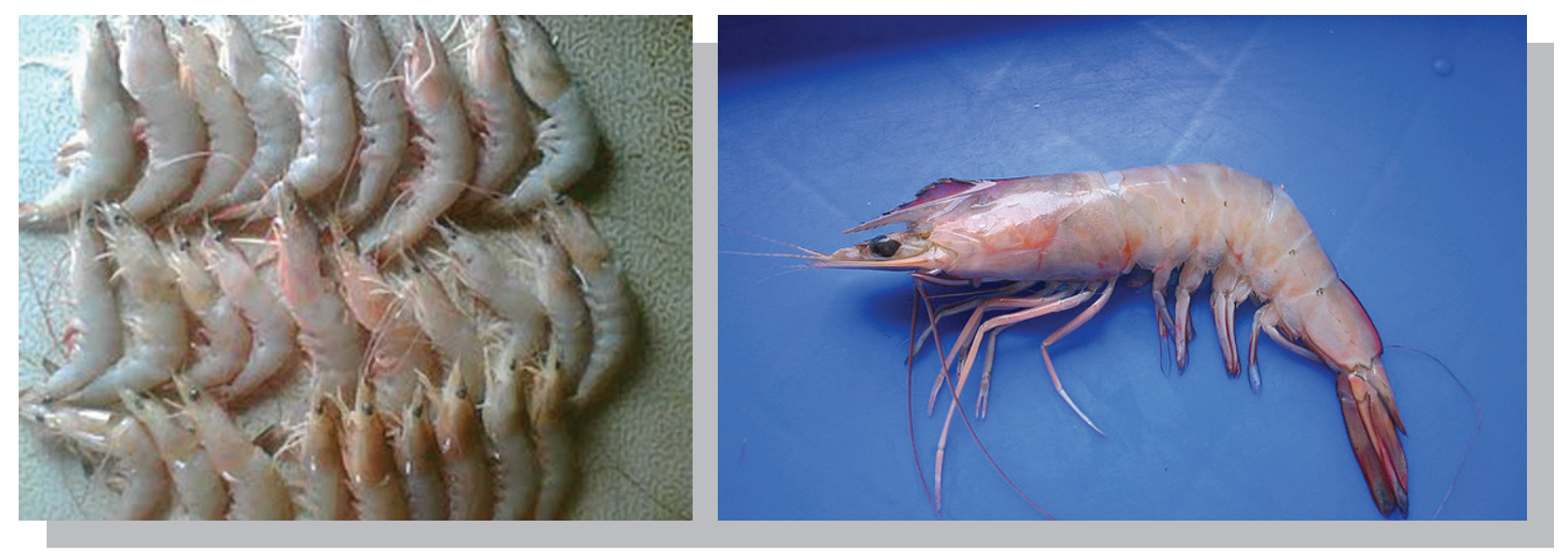

Gambar 3. Performa udang jerbung (F. merguiensis) dari perairan Cilacap, Jawa Tengah 
Menurut Hoang (2001), jika dibudidayakan udang jerbung mempunyai keunggulan-keunggulan antara lain adalah bahwa udang tersebut dapat matang gonad dan memijah dari induk hasil budidaya tambak. Pemeliharaan larva relatif mudah dengan laju pertumbuhan yang cepat, toleran pada kisaran salinitas serta temperatur yang lebar, tingkat variabilitas ukuran rendah, dan kebutuhan pasar stabil. Oleh karena itu, kegiatan pembenihan udang jerbung harus digalakkan sehingga kegiatan budidayanya maju. Haryanti et al. (2005) teknik pembenihan udang jerbung perlu segera direalisasikan mengingat udang tersebut mempunyai kesempatan untuk dibenihkan secara independen tanpa bergantung pada induk alam. Udang jerbung dapat menjadi kandidat program domestikasi atau selektif breeding untuk produksi induk yang memiliki pertumbuhan cepat dan tahan penyakit serta peningkatan biodiversitas spesies budidaya sehingga lebih memantapkan produksi udang secara industrial.

\section{UPAYA PENYEDIAAN INDUK GUNA MERINTIS USAHA PERBENIHAN}

\section{Sumber Induk}

Penyediaan induk merupakan mata rantai utama yang sangat menentukan kelancaran produksi secara keseluruhan. Calon induk dapat diperoleh dari berbagai sumber perairan di laut. Induk matang gonad yang diperoleh dari laut umumnya mempunyai fekunditas yang sangat tinggi dibandingkan dengan induk yang dibesarkan di tambak. Menurut Cholik et al. (1988), induk matang gonad yang ditangkap dari laut mampu memproduksi telur sebanyak 100.000-1.000.000 butir sedangkan induk yang dibesarkan di tambak hanya menghasilkan telur 100.000400.000 butir. Dengan demikian banyak nelayan maupun pembudidaya yang mempunyai anggapan bahwa induk yang matang gonad dari laut menghasilkan nauplii yang lebih sehat/kuat dibandingkan induk dari tambak.
Berdasarkan penelitian yang dilakukan terhadap udang windu oleh panti-panti benih udang, mereka memilih dan menyukai induk yang matang gonad dari laut. Hal tersebut disebabkan induk yang berasal dari tambak matang gonadnya lebih lambat. Oleh karena itu, untuk usaha perbenihan udang jerbung juga disarankan untuk menggunakan induk-induk yang memenuhi syarat seperti halnya yang dilakukan pada udang windu.

\section{Perawatan Induk}

Calon induk yang terpilih selanjutnya dilakukan aklimatisasi dalam bak-bak penampungan atau perawatan. Aklimatisasi perlu dilakukan karena udang merupakan hewan laut yang mudah sekali mengalami gangguan keseimbangan biologis apabila dipindahkan ke dalam lingkungan yang baru. Proses dilakukan mengacu pada udang-udang penaeid yang lain, baik udang windu, vaname, udang putih yang selama ini telah berhasil budidayanya, yaitu dilakukan secara sederhana dengan menampung induk-induk baru ke dalam bak yang bersih dan diisi air yang berkualitas baik. Setelah aklimatisasi induk dipelihara dalam bak perawatan sampai matang gonad. Penanganan induk yang matang gonad juga mengacu pada udang windu dan vaname mengingat belum ada budidaya intensif untuk udang jerbung ini. Induk udang jerbung yang telah mencapai tingkat kematangan gonad III dipisah ke dalam bak penetasan (Primavera, 1985).

Proses selanjutnya dalam budidaya udang jerbung yang perlu diperhatikan adalah teknik pemeliharaan larva, persediaan pakan alami untuk larva, perkembangan larva, dan pembesarannya, serta seleksi calon induk yang unggul untuk persediaan budidaya udang jerbung yang berkelanjutan. Pada Gambar 4 disajikan beberapa contoh induk dan larva udang jerbung.

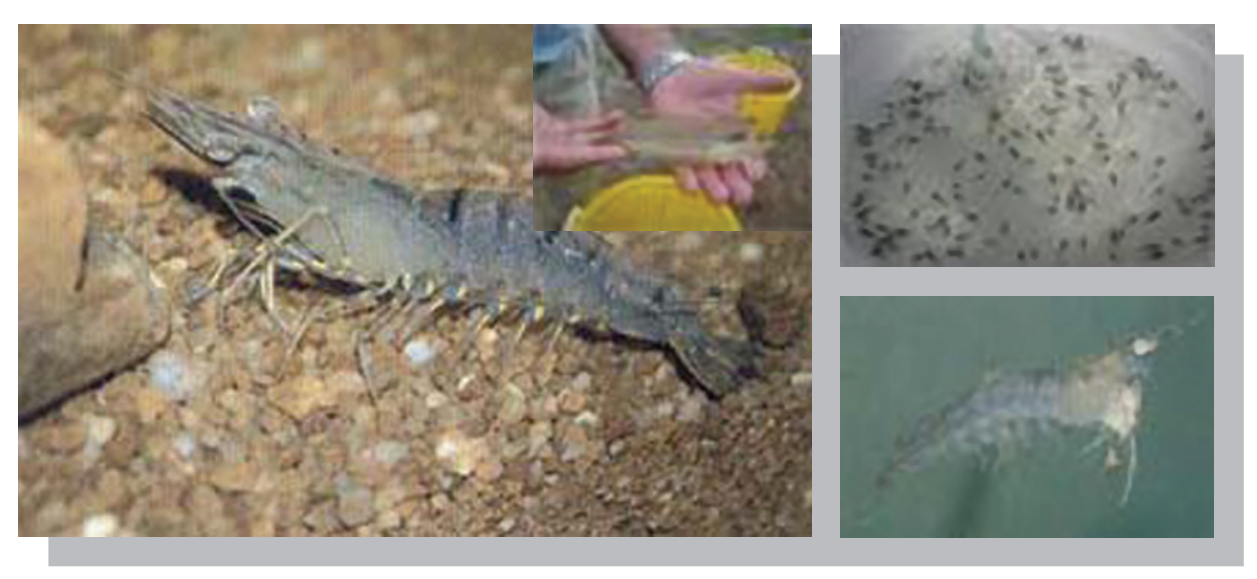

Gambar 4. Keragaan induk dan larva udang jerbung (F. merguiensis) 


\section{PENYEDIAAN INDUK UDANG JERBUNG}

Kebutuhan induk yang unggul sangat penting dalam usaha perbenihan. Jumlah kebutuhan induk tentu saja sangat fluktuatif tergantung dari skala produksi. Tidak menutup kemungkinan dari tahun ke tahun semakin meningkat dan semakin kekurangan apabila budidaya udang jerbung ini telah berhasil dan berskala luas. Sebagaimana yang dialami pada budidaya udang windu yang masih sulit mendapatkan induk unggul hasil tambak, dan kadang-kadang masih menjadi masalah kekurangan induk di panti-panti perbenihan, maka sejak dirintis usaha perbenihan udang jerbung sebaiknya mulai memproduksi dan menyeleksi individu yang dapat dijadikan calon induk unggul.

Untuk itu, perlu diteliti dan dikembangkan juga teknologi penyediaan induk udang jerbung asal tambak yang kualitasnya setara dengan calon induk yang berasal dari laut. Penelitian yang demikian ini untuk udang jerbung perlu dimulai sejak dini.

\section{KESIMPULAN}

1. Udang jerbung merupakan salah satu udang penaeid belum dilakukan budidayanya, dan untuk memenuhi permintaan pasar masih mengandalkan tangkapan alam.

2. Usaha perbenihan hendaknya segera dirintis secara serius mengingat udang jerbung tersebut mempunyai habitual dan kondisi biologi yang hampir sama dengan udang windu, sehingga tidak terlalu sulit untuk dilakukan budidayanya di tambak.

3. Udang jerbung di alam masih memungkinkan untuk diperoleh calon-calon induk yang baik dan cukup dalam pemenuhan usaha perbenihan.

\section{DAFTAR ACUAN}

Adi, C.P. 2007. Optimasi Penangkapan Udang Jerbung (Penaeus merguiensis de Man) di Lepas Pantai Cilacap. Tesis. Sekolah Pascasarjana, IPB, $47 \mathrm{hlm}$.
Cholik, F., Azwar, Z.I., \& Suwirya, K. 1988. Teknologi produksi benih udang windu (Penaeus monodon Fabr.). Prosiding Seminar Nasional Perbenihan Ikan dan Udang. Balitbang Pertanian, hlm. 200-223.

Farfante, P.I. \& Kensley, B. 1997. Penaeoid and sergestoid shrimps and prawns of the world. Keys and diagnoses for the families and genera. Mémoires du Musée nationale de I'Histoiré naturelle, Paris, 175: 1-233.

Haryanti, Moria, S.B., Permana, G.N., Wardana, K., \& Mozaki, A. 2005. Pembenihan Penaeus semisulcatus/ Penaeus merguiensis serta pemantapan teknik pembenihan Litopenaeus vannamei melalui kontrol biologi. Laporan Proyek Penelitian. Balai Besar Riset Perikanan Budidaya Laut, Gondol, $17 \mathrm{hlm}$.

Hoang, T. 2001. The Banana prawn-the right species for shrimp farming. J. World Aquaculture Soc., 32(4): 4043.

Koswara, B. 1985. Stok Udang Jebung (Penaeus merguiensis de Man) di Perairan Cirebon dan Alternatif Pengelolaannya. Tesis. Program Pascasarjana. IPB, 74 pp.

Martosubroto, P. 1977. Musim pemijahan dan pertumbuhan udang jerbung, Penaeus merguiensis de Man dan udang dogol, Metapenaeus ensis de Haan di perairan Tanjung Karawang. Prosiding Seminar ke-II Perikanan Udang, 15-18 Maret 1977, Jakarta, hlm. 7-20.

Naamin, N. 1975. Synopsis Biologi Udang Penaeid (Penaeus merguiensis de Man), Penaeus monodon Fabricus. Bahan pendidikan. Jakarta. Departemen Pertanian, Balai Penelitian dan Pengembangan Perikanan, Lembaga Penelitian Perikanan Laut.

Naamin, N. 1984. Dinamika Populasi Udang Jerbung (Penaeus merguiensis de Man) di Perairan Arafura dan Alternatif Pengelolaannya. Disertasi. Fakultas Pascasarjana Institut Pertanian Bogor. Bogor, 185 hlm.

Primavera, J.H. 1975. Sugpo (Penaeus monodon Fabr.). Aquaculture Departement SEAFDEC. Tigbanan Iloilo Philippines, 15 pp. 